\title{
Importance of Kashyapa's Vedanaadhyaya in Diagnosis of Pediatric Disorder: A Review Article
}

\author{
Nisha Sharma, Prem Prakash Vyas and Harish Kumar Singhal* \\ PG Department of Kaumarbhritya, Dr. S R Rajasthan Ayurved University, India
}

Submission: November 06, 2020; Published: December 08, 2020

*Corresponding author: Harish Kumar Singhal, PG Department of Kaumarbhritya, Dr. S R Rajasthan Ayurved University, Jodhpur, Rajasthan, India

\begin{abstract}
In Ayurveda dosha, dushya, mala and disease are similar in children as adult but vitiation of dosha, dushya and mala is somewhat in lesser extent in children as compared to adult. Thus, disease arise in children is not as aggressive and complicated as in adult. Therefore, it is very difficult to make diagnosis of disease. Acharya Kashyapa is the father of ancient pediatrics who described about avachsa (unable to speak) nature of child in their treatise. In such situation, diagnose a child suffering from an ailment is quiet difficult. To overcome this situation Acharya Kashyapa described a chapter named vedanaadhyaya in his treatise Kashyapa Samhita. In this chapter he enumerates purvaroops (prodromal features) and roops (symptoms) of nearly 30 diseases. Thus, in present era this chapter enlightens us his deep knowledge regarding to understand the children's problem. So, keep these things in mind author try to explore this chapter in today perspective with supporting evidence.
\end{abstract}

Keywords: Kashyapa Samhita; Vedana Adhyay; Prodromal symptoms; Children

\section{Introduction}

Kashyapa Samhita is main authentic book for Kaumarbhritya that illustrate symptoms of children and help in diagnosis of disease. Neonatal and infancy period is very critical period because the baby depends upon other person like mother or wet nurse for fulfilling all his requirements. Healthy neonate/infant can grow well, feed/eat well, plays and sleep well but uneasiness experienced by the child could not easily express. Infant has got poverty of words as well as symptoms leading to difficulty and confusion in understanding the exact underlying disease. Acharya Kashyapa mentioned symptomatology of various diseases in Vednaadhyay [1] Kashyapa Samhita and these symptoms are very nearly relevant to modern symptomatology.

\section{Materials \& Methods}

Vedanaadhyaya of Kashyapa Samhita published by Chaukhambha Sanskrit Sansthan, Varanasi, edition reprint 2009 (ISBN 8186937-67-6) was kept in center for this review. Relevant materials were searched and collected from other Samhita, published books, journals and internet web search. After thoroughly going in all the sources, a critical review was done over the same which is tried to be elaborated in this manuscript.

\section{Shirahshool}

In the event of headache, the child rolls him head too much, closures of eyes, create grunting like sound, discomfort/ restlessness and disturbed sleep [2].

Relevance:- Headache is very common complaint in childhood. It can occur as a disease (primary) or occur as symptom of other disease (secondary). Most common type of headache in childhood is migraine and tension type headache [3]. Most of children cannot convey the symptom of headache rather they may become cranky and irritable and having vomit or repeatedly rub their eye and head. Prefer a dark room because of photophobia. Similarly, Acharya Kashyapa was also mentioned features resemble to modern science like shirah spandyati (rolling his head due to irritability), nimiliyati chakshushi, closing of eyes due to photophobia etc [4].

\section{Karna Vedna}

Child continuously touching him ear by hand, tossing of head, discomfort, anorexia, insomnia [5]. 
Relevance:- Karna Vedna or pain in ear is called otalgia. Symptoms include child pulling and rubbing the ear with irritability and poor sleep, generally associated with fever. Reason behind otalgia includes inflammation in ear due to any infection (otitis media, otitis externa), foreign body in ear [6] etc. Acharya Kashyapa also mentioned symptoms like karno sparshyati hastabhyam means frequent touching or rubbing his ear, shriobhramyat, arati, arochka etc.

\section{Mukha Roga}

In Mukharoga Acharya Kashyapa mentioned that child, having excessive salivation, refusal to feed, regurgitation of milk, nasal breathing, discomfort and glani (fatigue) [7].

Relevance:- All these symptoms described by Acharya Kashyapa represent a wide range of oral cavity disease, i.e. dental caries, gingivitis, palate disease, ulcers/blisters in mouth etc. Excess salivation is found in swelling of gums where oral cavity ulcer causes difficulty in breast feeding. Inflammation in tonsillitis causes painful swallowing or regurgitation of breast milk [8].

\section{Kantha vedna}

The child suffering from throat pain eject the ingested milk, constipation, desire to take kaphaj Aahar, has mild fever, anorexia and fatigue [9].

\section{Galgrha}

In this disease child have hyperthermia, anorexia, salivation and emit a long breath [10].

\section{Kantha Shotha}

In kantha shotha there is itching and inflammation in throat and child also having fever anorexia and headache [10].

Relevance: - Symptom described in Kanthvedna, Galgrah and Kanthshotha are found in tonsillitis, adenoids, diphtheria and pharangitis. Both tonsils and adenoids are main cause of upper airway obstruction in children, symptoms include malaise, fever, dysphasia, headache are found as Jawar, Aruchi, Glani [11]. Sore throat, malaise and mild to moderate fever, mild pharyngeal, erythema are found in diphtheria [12].

\section{Adhijivhika}

In presence of adhijivhika child having excessive salivation, anorexia, discomfort, swelling and pain in cheeks, opening of mouth etc. [13]

Relevance: - Adhijivhika is correlate with epiglottitis, it is a condition where high grade fever, sore, throat, dysphasia and rapidly progressing respiratory obstruction is found. Drooling of saliva is usually present. These symptoms are resembling the features described in Adhijivhika i.e. lalastrav, aruchi, glani etc. [14]

\section{Jwar}

In the episode of fever child bend his body parts in abnormal postures repeatedly, frequent yawns and cough, suddenly clings to his or her mother, dislike the breast feed, excessive salivation, raised body temperature, discoloration, excessive warmth in forehead, anorexia and coldness of feet are seen [15].

Relevance: - Fever is defined as a rectal temperature more or equal to 380C (100.40F ). Symptoms of fever can be varying in a range from no symptoms to extreme malaise, fatigue, and irritability. Children might complaint of hot or cold feeling shivering [16]. These symptoms also mentioned in Kashyapa Samhita i.e. Aruchi (anorexia), Satanyamnaabhinandati, Dhatrimaalyate akasmat that might be possible when child suffering from cold or shivering.

\section{Atisar}

Discoloration of the body, restlessness, dullness on face, insomnia, disturbance in vata's normal functioning are symptoms of Atisar [17].

Relevance: - Diarrhea is defined as loss of fluid and electrolyte in the stool; it is the main cause of morbidity and mortality in children [18]. Symptoms described in Atisar in Kashyapa Samhita are similar to diarrhea i.e. Dehvaivrnayam or paleness found due to fluid loss in body. Other symptom like Arati (discomfort), Glani (fatigue), Anidra (insomnia) are also found due to fluid loss or dehydration.

\section{Shool}

Dislike the breastfeed, frequent cry, sleeps in supine position, having stiffness of abdomen, coldness and sweating on face [19].

Relevance:- Udar Shool can be correlate with infantile colic. Infantile colic is a common disease that can be found in 2-3 week of age to 3-4 month of age. Crying episodes are the main feature [20]. It is associated with fussiness, irritability and difficulty to consoling the child [21].

\section{Chardi}

Regurgitation without any reason, frequent eructation, loss of sleep, excessive yawning are symptoms of Chardi [22].

Relevance:-Vomiting is a coordinated reflex incidence that may be preceded by increased salivation and begins with involuntary retching. Complication due to vomit are dehydration fluids loss, failure to thrive [23].

\section{Shwasa and Hikka}

Emit excessive hot breath and difficult or labored breath develops in Shwasa while sudden eructation of vata is the symptoms of Hikka [24]. 
Relevance: - Nishtnuatushna means difficulty in breathing \& hot breath. In modern science difficulty in breathing is called dyspnoea that is a symptom of many respiratory disorders.

\section{Trishana}

Symptoms like unsatisfied child after too much feed, aggressively cry with dry lips and palate with desire for water, he seem to weak are described in trishana [25].

Relevance:-Symptoms described by Acharya Kashyapa in trishana are similar to moderate dehydration that occurs due to various disorders such as diarrhea, Vomiting and diabetes mellitus.

\section{Aanah}

Wide open eyes stretches and squeeze fingers due to pain, discomfort, seem exhaust, and retention of urine, flatus and feces [26].

Relevance:- On the basis of clinical features of Anah. It can be correlated with constipation and abdominal pain. Hard and large stool in the rectum become difficult and even painful to evacuate [27]. Acharya Kashyapa says Vishalstabdha nayna, Arati and klma as symptoms of Anah, these symptoms develops due to pain in defecation and Sarundhamutra Anilvitta shows difficulty in passes of urine and stool.

\section{Apasmar}

Child starts laughing all of a sudden is seen in Apasmar [28].

Relevance:- Symptoms described in Apasmar by Acharya Kashyapa resemble to epilepsy. Epilepsy is a disorder of the brain characterized by an enduring predisposition to develop seizures and by neurobiological, cognitive, psychological and social consequences of this condition [29].

\section{Unmad}

Child more talkative, restlessness, irrelevant speech are the symptoms of Unmad [28].

Relevance:- Symptoms described in Unmad can be seen in psychosomatic disorders like attention deficit hyperactivity disorders (ADHD), opposite defiant disorders (ODD), pervasive developmental disorders (PDD) and autism spectrum disorders (ASD) etc.

\section{Mutrakricha}

In this disease, there is horripilation, shivering of body and painful urination. Child bites his lips and frequently touches the urinary bladder [30].

Relevance: - Symptoms described under the heading of Mutrakricha by Acharya Kashyapa are found in urinary tract infection. A urinary tract infection (UTI) in children is a fairly common condition. Bacteria that enter the urethra are usually flushed out through urination. However, when bacteria are not expelled out of the urethra, they may grow within the urinary tract. This causes an infection. When bacteria enter the urinary tract and travel up the urethra and into the body. The two types of UTIs most likely to affect children are bladder infection and kidney infection. Symptoms of a UTI can vary depending on the degree of infection and your child's age. Infants and very young children may not experience any symptoms. When they do occur in younger children, symptoms can be very general. They include fever, loss of appetite, irritability, cloudy and foul smell urine, pain, stinging or burning during urination with frequency, urgency and hesitancy. Prompt diagnosis and treatment will prevent serious and long-term medical complication [31].

\section{Prameha}

In Prameh body becomes heavy, inert \& rigid , sudden passage of white and thick urine, hence flies contact [32].

Relevance: - Diabetes mellitus, commonly known as diabetes, is a metabolic disease that causes high blood sugar. The hormone insulin moves sugar from the blood into cells to be stored or used for energy. With diabetes, body either does not make enough insulin or cannot effectively use the insulin it does make. Untreated high blood sugar from diabetes can damage nerves, eyes, kidneys, and other organs. It is of mainly of two type: Type - 1 Insulin dependent diabetes mellitus (IIDM) and Type-2 Non-insulin dependent diabetes mellitus [33]. Type 1 Diabetes Mellitus is an autoimmune disorder in which immune system attacks and destroys insulin producing cells in pancreas however its cause is not yet clear. About 10 percent of child is suffering this disease. Symptoms described by Acharya Kashyapa are having close resembled to this IDDM type -1 DM.

\section{Arsh}

Constipation and blood in feces; pressure, pain \& itching of anus and emaciation [34]

Relevance:-Symptoms described by Acharya Kashyapa seems to bleed hemorrhoids in which child shows constipation or passes hard and tight stool which cause erosion in rectal mucosa. Due to this bleeding is seen. If this continue then it causes anemia in such children. When an internal hemorrhoid prolapsed, it brings along mucus that can irritate the sensitive area around the anus causing itching. If the hemorrhoid stays prolapsed, mucus production continues and so does the itching. If stool mixes with the mucus, that combination can make the irritation, and thus the itching [35].

\section{Ashmari}

Passing of excessive urine with sandy content and pain during urination. Child is excessively weeping and emaciated [36]. 
Relevance: - Above symptoms described by Acharya Kashyapa are similar to symptoms seen in urinary calculi. Approximately $7 \%$ of urinary calculi occur in children younger than $16 \mathrm{yr}$ of age [37]. The composition and site of urinary calculi vary, depending on the pathogenesis. Most stones are composed of calcium, oxalate, uric acid, cystine, ammonium, or phosphate crystals [38]. Children with urolithiasis usually has gross or microscopic hematuria. If the calculus is in the renal pelvis, calyx, or ureter and causes obstruction, then abdominal or flank pain (renal colic) occurs. Typically, the pain radiates anteriorly to the scrotum or labia. Often the pain is intermittent, corresponding to periods of obstruction of urine flow, which increases the pressure in the collecting system. If the calculus is in the distal ureter, the child may have irritative symptoms of dysuria, urgency, and frequency. If the stone has passed into the bladder, the child is usually asymptomatic. If the stone is in the urethra, dysuria and difficulty voiding may result. Some children pass small amounts of gravel-like material [37].

\section{Visarpa}

Eruption of red burning wheels on skin, fever and thirst; palliation from sweet and cold things, are the prodromal symptoms of visarpa [39].

Relevance: - On the basis of clinical presentation of Virsarpa it can correlate with erysipelas. It is a superficial variant of cellulitis usually caused by group A streptococcus that involves the dermis only. The rapidly advancing lesions are tender, bright red in appearance, and have sharp margins [40].

\section{Visuchika}

Burning sensation over the body, needle pricking like pain broken like pain, difficulty in breathing and increasing pain in chest region. are the symptoms of Visuchika [41].

Relevance:- These symptoms similar to cholera gravis, the most severe form of gastroenteritis which is characterized by sudden onset of profuse watery diarrhea followed by vomiting and severe dehydration. Diagnosis can be confirmed by direct microscopy of samples of stool, vomius, water or food. Under the dark illumination the organism appears as several shooting stars in a dark sky. On complication it causes acute renal failure, paralytic ileus, pulmonary edema and arrhythmias. Prompt diagnosis and treatment can save child life [42].

\section{Alasaka}

A child suffering from alasaka is unable to hold his head with breaking pain in his body. Frequent yawning is present. He shows reluctance to breast milk. If he or she breastfeeds milk then vomit it as knotty material, shows loss of appetite with flatulence and sadness [43].

Relevance:- These symptoms correlate to intestinal obstruction. In the newborn cause of obstruction is congenital malformation e.g. congenital atresia of oesophagus, congenital pyloric stenosis, Meconium ileus, congenital atresia of the duodenum ileum, necrotizing enterocolitis, volvus, Hirschsprung's disease. In infancy intussusceptions and worm infestation are the main aetiology. Later on besides intussusceptions band or adhesions resulting from meckel's diverticulum or local peritonitis due to appendicitis, tubercular peritonitis and tabes mesenterica are the leading cause in childhood. Intestinal colic, vomiting, distension, constipation and dehydration are common clinical features seen in intestinal obstruction [44]. Symptoms described by Acharya Kashyapa under the heading of alsaka are closely resemble to intestinal obstruction occurs due to necrotizing enterocolitis. It is devastating disease that affects mostly the intestine of premature infants. The wall of the intestine is invaded by bacteria, which cause local infection and inflammation that can ultimately destroy the wall of the bowel (intestine). Overall, NEC affects one in 2,000 to 4,000 births, or between one percent and five percent of neonatal intensive care unit admissions. The disease occurs in nearly 10 percent of premature infants but is rare in full term infants. NEC typically develops within the first 2 weeks of life in a premature infant who is being fed with formula as opposed to breast milk. One of the first signs of NEC is the inability of the infant to tolerate the feedings. This is often associated with abdominal distention (bloating) and vomiting bile (green). The infant may also have bloody stools because of the infection of the bowel wall. If the infection is not recognized early, then the child may develop a low respiratory rate or periodic breathing (apnea) and a low heart rate that may necessitate insertion of a breathing tube. Other findings may include a red and tender abdomen diarrhea, lethargy (listlessness) and shock (decreased blood pressure). Prompt diagnosis and treatment of NEC can protect infant from surgery and other complication $[45,46]$. In terms of Ayurveda when vata increased then it associates with kapha and obstruct the movement of undigested food inside cause stay like foreign body with severe abdominal pain, vomiting and diarrhea.

\section{Akshi Roga}

Child suffering from akshi roga have disturbed vision, pain, oedema, lacrimation and redness in eyes. Due to which eyes get smeared after sleeping [47].

Relevance: - Features described in akshi roga very much near to allergic or infectious conjunctivitis (viral, bacterial and ophthalmic neonatorum), blepharitis, eye injury, ingrown eye and sty etc. Symptoms due to these disorders are pain, redness, blurred vision, sensitivity to light, and excess tearing in eyes. Prompt diagnosis and treatment of these disorders can prevent various complications in eyes.

\section{Kandu}

Rubbing the body parts continuously during sleep, he will cry and rubbing his body. These symptoms are considered in dry itching after frequent rubbing convert in wet lesions, in which child 
get pleasure on rubbing, this rubbing causes swelling and oozing from lesion. Wet itching has Pain and burning sensation [48].

Relevance:- Features described under the heading of Kandu by Acharya Kashyapa can be closely resemble to atopic dermatitis in children. It is a common condition severely affecting $1-2 \%$ of school children. [49]. It is a chronic inflammatory skin disease in children who have genetic propensity of immunoglobulin E (IgE) mediated type I response (atopy) to environmental allergens, from in many diseases as a symptom (itching). Usually appears $50 \%$ below 1 year of age and $90 \%$ under 5 years of age. Early presentation includes erythema, scaling, intense itching, excoriation, weeping, secondary infection and sleep deprivation due to itching. Ongoing on severity it shows widespread areas of dry skin, incessant itching, and redness with or without excoriation, extensive skin thickening, bleeding, oozing, cracking and alteration of pigmentation. Exclusive breastfeeding during first six month along with avoidance of trigger factors lower its incidences. In moderate to severe cases use of emollients, corticosteroids and calcineurin inhibitors topical application provide wonderful result [49].

\section{Aama}

Stiffness, tastelessness, excessive sleep, paleness in body, reluctance to wet nurse along with diet, sleep, walking and playing. Unclean child look like clean whether clean child look like unclean are described by Acharya Kashyapa under the heading of Aam [50].

Relevance: - Due to excessive intake kapha vitiated breast milk it causes srothavarodha. Therefore, proper formation of rasa is affected and in place of rasa, toxic material (ama) is produced. This aama on lodging at different places cause related symptoms.

\section{Pandu}

Swelling around umbilicus, pallor in eye and face, typical deformities in nails, loss of appetite and edema around eye are common feature seen in pandu roga [51].

Relevance:- On the basis of clinical features given by Acharya Kashyapa it can correlate with iron deficiency anemia. It is the most common form of nutritional anemia which is very common in infancy because both breast and cow milk are deprived of iron and second cause is poor iron store in premature babies predispose to IDA nearby third month of age. Affected child shows progressive pallor, irritability, loss of appetite, tiredness, weakness, tachycardia, nail deformities such as spoon shaped nail (koilonychia) or flat nail (platonychia). In severe anemia liver and spleen get enlarged along with whitening of palmer crease. Later on, hemic murmur, unhappiness, lack of cooperation and shorter attention is seen. Peripheral smear shows microcytic hypochromic RBC with anisopoiklocytosis with reduced serum iron and ferritin. TIBC is increased. Prompt diagnosis and treatment can prevent various complications [52,53].

\section{Kamla}

Yellowish discoloration of eyes, face, nails, feces and urine. In both Pandu \& Kamala child becomes apathetic and shows poor digestive fire along with desire for blood [54].

Relevance: - The symptoms described by Acharya Kashypa in Kamla are similar to the features found in neonatal jaundice. About $60 \%$ of term and $80 \%$ of preterm infants develop jaundice during first week of life. Most of the jaundice of the newborns is physiological. Most common causes of unconjugated hyperbilirubinemia are prematurity, breast milk jaundice, haemolytic disease of newborn (HDN) (ABO \& Rh incompatibility), congenital or acquired sepsis, cephalohematoma, bruising, hypothyroidism, crigler-najjar syndrome etc. Common clinical features are yellowish discoloration of the eye, face, nail, feces and urine with loss of appetite. Jaundice in neonates develops in cephalocaudal direction [55]. When serum total bilirubin crosses $20 \mathrm{mg} / \mathrm{dl}$ then it crosses blood brain barrier and cause severe hyperbilirubinemia or kernicterus. This severe hyperbilirubinemia can cause encephalopathy with important sequel among surviving infants, including athetotic cerebral palsy, sensory neural hearing loss, paralysis of upward gaze and dental enamel dysplasia. At this time exchange blood transfusion [56] saves neonate life which can justify desire of blood as per narration roodhirsprha by Acharya Kashyapa.

\section{Pinasa and Uroghat}

Mouth breathing, interval of breast sucking to have proper breathing, running nose, hot forehead, sneezing, cough, compressed chest and features as that of pinasa. Rapid thoracic breathing occurs in Uroghat [57].

Relevance: Above features of Pinasa can be correlated with infection of nasopharynx which is called as common cold or acute nasopharyngitis. It is the most common infection in children whose 5 to 8 episodes occur in one year. It is caused by viruses like rhinovirus, adenoviruses, influenza, parainfluenza or respiratory syncytial viruses and corona viruses. These are spread by droplet infection. Predisposing factors include chilling, sudden exposure to cold air, and overcrowding. Rhinitis could also be due to allergy. Clinical manifestations are more distressing in infants and young children. The common manifestation includes nasal discharge, initially watery than thick white to yellowish, nasal block, cough and conjunctival congestion. Nasal block causes difficulty in feeding, irritability, excessive crying and breathing from mouth. Occasionally may be complicated by secondary bacterial sinusitis and otitis media. Acute nasopharyngitis is caused by virus and selflimiting requires no specific treatment [58].

\section{Madatyaya}

Acharya Kashyapa enumerate symptoms of madatyaya as fainting, insomnia, vomiting, reluctance to feed, dullness, vertigo, thirst, fear and emotion [59]. 
Relevance:- Mother of breast-feeding child who drank quite heavily leads to intoxication. When she fed her baby then baby shows drowsiness, stupor or coma, disturbed sleep, vomiting due to gastric irritation, abnormal behavior, restlessness etc. Such symptom can also be seen in accidental alcohol poisoning in infant or child [60].

\section{Jantu-dansha}

In this condition child suddenly lost sleep in night and red colour patches are seen on the body [61].

Relevance:- Above features of jantudansha can be compared as lesions occurs due to insect bite. In such lesion, generally a pruritic eruption at the bite site with local erythematic patch wheels and urticaria [62].

\section{Conclusion}

Above description clarify this very keenly that Ancient Sage Acharya Kashyapa has very deep knowledge to understand the disorders occur in children. This also shows that how beautiful all features were collected by Acharya Kashyapa and enumerate them in beautiful chapter as Vednaadhyaya in his treatise Kashyapa Samhita. Here an effort is made here to correlate them in today's perspective which will be helpful to understand the disease of children in initial stage as well as their treatment accordingly without any complications. Thus, by adopting these in day to day practice we prevent morbidity and mortality in children.

\section{References}

1. Bhishagacharya SS. Kashyapa Samhita with Hindi commentary Vidyotini, Reprint edn 2006, published by Chaukhambha Sanskrit Series, Varanasi, Sutra Sthana, Chapter 25, Verse no.1-5. p. 33.

2. Bhishagacharya SS. Kashyapa Samhita with Hindi commentary Vidyotini, Reprint edn 2006, published by Chaukhambha Sanskrit Series, Varanasi, Sutra Sthana, Chapter 25, Verse no.6. P.33

3. Kliegman, ST Geme, Nelson Textbook of Pediatrics, $21^{\text {st }}$ Edn, Elsevier, p. 12201.

4. Deepshika Amit Kumar Rai (2016) Vedhnaadhyay a crucial contribution of Kashyapa Samhita in Pediatric Clinical Examination , January 2016, IJAPAR.

5. Bhishagacharya SS (2006) Kashyapa Samhita with Hindi commentary Vidyotini, Reprint edition 2006, published by Chaukhambha Sanskrit Series, Varanasi, Sutra Sthana, Chapter 25, Verse no.7. p.33

6. Kliegman, ST Geme. Nelson textbook of Pediatrics, $21^{\text {st }}$ edn, Elsevier pp. 13128.

7. Bhishagacharya SS (2006) Kashyapa Samhita with Hindi commentary Vidyotini, Reprint edition 2006, published by Chaukhambha Sanskrit Series, Varanasi, Sutra Sthana, Chapter 25, Verse no.8. P.33

8. Kliegman, ST Geme, Nelson Textbook of Pediatrics, $21^{\text {st }}$ Edn, Elsevier Page 5293

9. Bhishagacharya SS. Kashyapa Samhita with Hindi commentary Vidyotini, Reprint edition 2006, published by Chaukhambha Sanskrit Series, Varanasi, Sutra Sthana, Chapter 25, Verse no.9. P.33
10. Bhishagacharya SS (2006) Kashyapa Samhita with Hindi commentary Vidyotini, Reprint edition 2006, published by Chaukhambha Sanskrit Series, Varanasi, Sutra Sthana, Chapter 25, Verse no.11. P.33

11. Kliegman, ST Geme, Nelson Textbook of Pediatrics, 21 edn, Elsevier, pp. 8691.

12. A Parthsarathy, IAP Textbook of Pediatrics, $6^{\text {th }}$ edn, reprint 2007, Jaypee publication, pp. 340 .

13. Bhishagacharya SS (2006) Kashyapa Samhita with Hindi commentary Vidyotini, Reprint edition 2006, published by Chaukhambha Sanskrit Series, Varanasi, Sutra Sthana, Chapter 25, Verse no.10. p. 33

14. Kliegman, ST Geme, Nelson textbook of Pediatrics, 21 edn, Elsevier, pp. 8706

15. Bhishagacharya SS (2006) Kashyapa Samhita with Hindi commentary Vidyotini, Reprint edition 2006, published by Chaukhambha Sanskrit Series, Varanasi, Sutra Sthana, Chapter 25, Verse no.12-13. p. 33.

16. Kliegman, ST Geme, Nelson textbook of Pediatrics, $21^{\text {st }}$ Edm, Elsevier, pp. 5646.

17. Bhishagacharya SS. Kashyapa Samhita with Hindi commentary Vidyotini, Reprint edition 2006, published by Chaukhambha Sanskrit Series, Varanasi, Sutra Sthana, Chapter 25, Verse no.14. p.34

18. Kliegman, ST Geme, Nelson textbook of Pediatrics, 21 edn, Elsevier, pp. 7575

19. Bhishagacharya SS. Kashyapa Samhita with Hindi commentary Vidyotini, Reprint edition 2006, published by Chaukhambha Sanskrit Series, Varanasi, Sutra Sthana, Chapter 25, Verse no.15. p. 34

20. Kliegman, ST Geme, Nelson textbook of Pediatrics, 21 edn, Elsevier, pp.1138

21. Kliegman, ST Geme, Nelson textbook of Pediatrics, 21 edition, Elsevier, pp. 8083.

22. Bhishagacharya SS. Kashyapa Samhita with Hindi commentary Vidyotini, Reprint edn 2006, published by Chaukhambha Sanskrit Series, Varanasi, Sutra Sthana, Chapter 25, Verse no.16. p. 34.

23. Kliegman, ST Geme, Nelson textbook of Pediatrics, 21 edn, Elsevier, pp. 7570 .

24. Bhishagacharya SS. Kashyapa Samhita with Hindi commentary Vidyotini, Reprint edition 2006, published by Chaukhambha Sanskrit Series, Varanasi, Sutra Sthana, Chapter 25, Verse no.17. p. 34

25. Bhishagacharya SS. Kashyapa Samhita with Hindi commentary Vidyotini, Reprint edition 2006, published by Chaukhambha Sanskrit Series, Varanasi, Sutra Sthana, Chapter 25, Verse no.18. p. 34.

26. Bhishagacharya SS. Kashyapa Samhita with Hindi commentary Vidyotini, Reprint edition 2006, published by Chaukhambha Sanskrit Series, Varanasi, Sutra Sthana, Chapter 25, Verse no.19. p. 34

27. Kliegman, ST Geme, Nelson Textbook of Pediatrics, 21 Edn, Elsevier, pp. 7580.

28. Bhishagacharya SS. Kashyapa Samhita with Hindi commentary Vidyotini, Reprint edition 2006, published by Chaukhambha Sanskrit Series, Varanasi, Sutra Sthana, Chapter 25, Verse no.20. p. 34

29. Kliegman, ST Geme, Nelson textbook of Pediatrics, 21 edn, Elsevier, pp. 12058.

30. Bhishagacharya SS. Kashyapa Samhita with Hindi commentary Vidyotini, Reprint edition 2006, published by Chaukhambha Sanskrit Series, Varanasi, Sutra Sthana, Chapter 25, Verse no.21. p.34.

31. Kliegman, ST Geme, Nelson Textbook of Pediatrics, 21 Edn, Elsevier, pp.10943. 
32. Bhishagacharya SS. Kashyapa Samhita with Hindi commentary Vidyotini, Reprint edition 2006, published by Chaukhambha Sanskrit Series, Varanasi, Sutra Sthana, Chapter 25, Verse no.22. p.34.

33. Kliegman, ST Geme, Nelson Textbook of Pediatrics, 21 Edition, Elsevier, pp. 11294.

34. Bhishagacharya SS. Kashyapa Samhita with Hindi commentary Vidyotini, Reprint edn 2006, published by Chaukhambha Sanskrit Series, Varanasi, Sutra Sthana, Chapter 25, Verse no.23. p.34.

35. Kliegman, ST Geme, Nelson Textbook of Pediatrics, 21 Edition, Elsevier.

36. Bhishagacharya SS. Kashyapa Samhita with Hindi commentary Vidyotini, Reprint edition 2006, published by Chaukhambha Sanskrit Series, Varanasi, Sutra Sthana, Chapter 25, Verse no.24 p. 34.

37. Kliegman, ST Geme, Nelson Textbook of Pediatrics, 21 edition, Elsevier, pp.1113.

38. Nicoletta JA, Lande MB. Medical evaluation and treatment of urolithiasis. Pediatr Clin North Am 53: 479-491.

39. Bhishagacharya SS. Kashyapa Samhita with Hindi commentary Vidyotini, Reprint edn 2006, published by Chaukhambha Sanskrit Series, Varanasi, Sutra Sthana, Chapter 25, Verse no.25. p. 34.

40. Karen J. Marcdante \& Robert M. Kleigman; Nelson Essentials of Pediatrics, $7^{\text {th }}$ edition, published by Elsevier publishers, London, pp. 1258

41. Bhishagacharya SS. Kashyapa Samhita with Hindi commentary Vidyotini, Reprint edition 2006, published by Chaukhambha Sanskrit Series, Varanasi, Sutra Sthana, Chapter 25, Verse no.26. p.35

42. Gupte Suraj; The short Textbook of Pediatrics, $13^{\text {th }}$ edition published by Jaypee Brothers Medical Publishers, New Delhi pp. 473-474.

43. Bhishagacharya SS. Kashyapa Samhita with Hindi commentary Vidyotini, Reprint edition 2006, published by Chaukhambha Sanskrit Series, Varanasi, Sutra Sthana, Chapter 25, Verse no.27-28. p. 35

44. Somen Das. A manual on clinical surgery, twelfth edn 2017 published by Dr. S. Das, Calcutta, India.

45. Chokshi NK. Guner YS. Hunter CJ (2008) Upperman JS. Grishin A. Ford HR. The role of nitric oxide in intestinal epithelial injury and restitution in neonatal necrotizing enterocolitis. Seminars in Perinatology. 32(2) 92-99.

46. Hunter CJ, Upperman JS, Ford HR (2008) Camerini V. Understanding the susceptibility of the premature infant to necrotizing enterocolitis (NEC). Pediatric Research 63(2): 117-123.

47. Bhishagacharya SS (2006) Kashyapa Samhita with Hindi commentary Vidyotini, Reprint edn 2006, published by Chaukhambha Sanskrit Series, Varanasi, Sutra Sthana, Chapter 25, Verse no.29. p. 35
48. Bhishagacharya S. S.: Kashyapa Samhita with Hindi commentary Vidyotini, Reprint edition 2006, published by Chaukhambha Sanskrit Series, Varanasi, Sutra Sthana, Chapter 25, Verse no.30-31. p. 35.

49. Shakur S.: Illustrated Textbook of Pediatrics $2^{\text {nd }}$ Edition (2015), published by Jaypee, The Health Science Publishers, New Delhi, pp. 835-837.

50. Bhishagacharya S.S (2006) Kashyapa Samhita with Hindi commentary Vidyotini, Reprint edition 2006, published by Chaukhambha Sanskrit Series, Varanasi, Sutra Sthana, Chapter 25, Verse no.32-33 p. 35

51. Bhishagacharya SS (2006) Kashyapa Samhita with Hindi commentary Vidyotini, Reprint edition 2006, published by Chaukhambha Sanskrit Series, Varanasi, Sutra Sthana, Chapter 25, Verse no.34, p. 35

52. Gupte Suraj; The short Textbook of Pediatrics, $13^{\text {th }}$ edition published by Jaypee Brothers Medical Publishers, New Delhi pp. 680-681.

53. Kliegman, ST Geme, Nelson Textbook of Pediatrics, 21 edn, Elsevier, pp. 9854

54. Bhishagacharya SS (2006) Kashyapa Samhita with Hindi commentary Vidyotini, Reprint edition 2006, published by Chaukhambha Sanskrit Series, Varanasi, Sutra Sthana, Chapter 25, Verse no.35, p. 35

55.Vinod K Paul, Arvind Bagga, OP Ghai Essential Pediatrics, $9^{\text {th }}$ Eddition2019 CBS publication, pp. 333.

56. Shakur S (2015) Illustrated Textbook of Pediatrics $2^{\text {nd }}$ Edition (2015) , published by Jaypee, The Health Science Publishers, New Delhi, pp. 111.

57. Bhishagacharya SS (2006) Kashyapa Samhita with Hindi commentary Vidyotini, Reprint edition 2006, published by Chaukhambha Sanskrit Series, Varanasi, Sutra Sthana, Chapter 25, Verse no.37-38 p. 36

58. Parthasarathy A; IAP Textbook of Pediatrics, fourth edition 2009, published by Jaypee Brothers Medical Publishers (P) Ltd, New Delhi, pp. 573

59. Bhishagacharya SS. Kashyapa Samhita with Hindi commentary Vidyotini, Reprint edition V.S. 2074, published by Chaukhambha Sanskrit Sansthsn, Varanasi, Sutra Sthana, Chapter 25, Verse no.39 p. 36

60. Kshma Gupta, Prasad Mamidi, Infant alcohol Exposure- Baala Madatyaya: An Ayurvedic view,Journal of Biological \& Scientidic Opinion, Review.

61. Bhishagacharya SS. Kashyapa Samhita with Hindi commentary Vidyotini, Reprint edition V.S. 2074, published by Chaukhambha Sanskrit Sansthsn, Varanasi, Sutra Sthana, Chapter 25, Verse no.40-49, p. 36.

62. Powers J, McDowell RH (2020) Insect Bite, Starpearls Publishing LLC. 
(C) This work is licensed under Creative Commons Attribution 4.0 License DOI: 10.19080/OROAJ.2020.17.555962
Your next submission with Juniper Publishers

will reach you the below assets

- Quality Editorial service

- Swift Peer Review

- Reprints availability

- E-prints Service

- Manuscript Podcast for convenient understanding

- Global attainment for your research

- Manuscript accessibility in different formats ( Pdf, E-pub, Full Text, Audio)

- Unceasing customer service

Track the below URL for one-step submission https://juniperpublishers.com/online-submission.php 